\title{
Axially Ligated Zirconium(IV) Tetraphenylporphyrin: Synthesis, Characterization, and Biological Activity
}

\author{
Gauri D. Bajju, Sunil Kumar Anand, and Gita Devi \\ P.G. Department of Chemistry, University of Jammu and Kashmir 180006, India \\ Correspondence should be addressed to Gauri D. Bajju; gauribajju@gmail.com
}

Received 30 May 2014; Revised 26 August 2014; Accepted 4 September 2014; Published 14 October 2014

Academic Editor: Claudio Pettinari

Copyright (C) 2014 Gauri D. Bajju et al. This is an open access article distributed under the Creative Commons Attribution License, which permits unrestricted use, distribution, and reproduction in any medium, provided the original work is properly cited.

A series of 5,10,15,20-tetraphenylporphinatozirconium(IV) acetylacetonatophenolates containing different phenols as axial ligands $[\mathrm{Zr}(\mathrm{TPP})(\mathrm{Y})(\mathrm{X})](\mathrm{TPP}=5,10.15,20$-tetraphenyl-21H, 23H-porphine; $\mathrm{Y}=$ acac; $\mathrm{X}$ = different phenolates) have been synthesized and characterized by various spectrochemical studies. The complexes were also screened for antimicrobial activities. Antifungal activity of some adducts has been carried out against the fungal strain Sclerotium rolfsii. Most of the complexes have shown good antibacterial activity.

\section{Introduction}

The present work is a continuation of our earlier work [1] where we have reported the synthesis of zirconium(IV) porphyrin complexes with salicylic acid and 5-sulfosalicylic acid which were made by replacing the two $\mathrm{Cl}^{-}$by the organic ligands and this was followed by a biological study on some of these compounds and in view of the interesting results obtained from such axially substituted zirconium(IV) porphyrin it is considered worthwhile to make a study of axially substituted zirconium(IV) porphyrin with phenol and its derivatives. The ability of numerous chemical modifications and the large number of different mechanisms by which porphyrins affect microbial and viral pathogens place porphyrins into a group of compounds with an outstanding potential for discovery of novel agents, procedures, and materials active against pathogenic microorganisms [2]. A variety of biological activities exhibited by porphyrins are due to the fact that natural and synthetic porphyrins have relatively low toxicity in vitro and in vivo and they possess antitumor $[3,4]$ and antioxidant effects $[4,5]$ and have a good potential for metal ions complexation. Metalloporphyrins are the basis of new antifungal, antiparasitic, and anticancer drugs because modification of the porphyrin periphery confers qualitatively a new spectrum of activities to metalloporphyrins [6-8]. Zirconium(IV) porphyrins have gained attention from global researchers due to the peculiar characteristics of this class of compounds. The peculiarity of these complexes lies in the fact that metal ion in the complexes, that is, $\mathrm{Zr}^{4+}$, has large ionic radius (72 pm for most $\mathrm{Zr}$ (IV) 6-coordinate complexes), which fits partly into the core of porphyrin ligand and hence shows "out of plane" geometry with additional ligands always in cis position relative to the porphyrin plane [9]. The metal ion in these complexes is oxophilic [10] and thus may show preference for carboxylate and other oxygen-bearing anionic ligands. A lot of work is reported on the complexes of zirconium(IV) phthalocyanines [11-13] but comparatively less work has been done on zirconium(IV) porphyrin complexes with phenol as axial ligand [14, 15]. With this background in mind we reported herein the synthesis, spectroscopic characterization, and biological studies of a series of new axially substituted zirconium(IV) porphyrin with phenol and its derivatives as axial ligands.

\section{Experiment}

2.1. Materials and Instruments. All the chemicals were of analytical grade and used as received unless otherwise noted. 
Pyrrole was distilled over potassium hydroxide pellets under vacuum prior to use. All the organic solvents that were used for the synthesis and for chromatographic separations were dried before use. UV-vis spectra were recorded on a T90+ UV/VIS spectrophotometer in the range of 350-700 $\mathrm{nm}$. The oscillator strength $(f)$ of the transitions in absorption spectra was calculated from the expression

$$
f=4.33 \times 10^{-9} \varepsilon \Delta v_{1 / 2}
$$

where $\varepsilon$ is the molar absorption coefficient in $\mathrm{dm}^{3} \mathrm{~mol}^{-1} \mathrm{~cm}^{-1}$ and $\Delta v_{1 / 2}$ is the full width at half maximum in $\mathrm{cm}^{-1}$. Infrared spectra were recorded on a PerkinElmer spectrum 400 FTIR spectrophotometer using $\mathrm{KBr}$ pellets in the range of 4000$400 \mathrm{~cm}^{-1}$. The elemental analysis was performed on Elemental Analyser CHNS-932, LECO, USA, at a temperature of about $1000^{\circ} \mathrm{C}$ using helium as carrier gas and oxygen for combustion. The ESI mass spectroscopy was recorded at room temperature and methanol was used as solvent. The ${ }^{1} \mathrm{H}$ NMR spectra were recorded on a Bruker Avance II $500(500 \mathrm{MHz})$ using tetramethylsilane as internal standard and $\mathrm{CDCl}_{3}$ as solvent. Fluorescence measurements were performed on Synergy MX BIOTEK multimode reader. The solution of porphyrins prepared in DMSO was $10^{-6} \mathrm{M}$.

\subsection{Biological Studies}

2.2.1. Antibacterial Studies. Qualitative analysis for screening of antibacterial activity was carried out by agar-well diffusion method [16] with modifications. By measuring the inhibition zone in $\mathrm{mm}$, the test compounds were taken at a concentration of $0.1 \mu \mathrm{M}$ using dimethyl sulfoxide (DMSO) as solvent. Chloramphenicol was used as positive control for antibacterial activity. The compound was tested against four gram positive bacteria (Bacillus subtilis, Bacillus cereus, Staphylococcus aureus, and Enterococcus faecalis) and four gram negative bacteria (Klebsiella pneumonia, Alcaligenes denitrificans, Campylobacter, and Micrococcus luteus). $20 \mathrm{~mL}$ of sterilized nutrient agar was inoculated with $100 \mu \mathrm{L}$ of bacterial suspension $\left(10^{8} \mathrm{CFU} / \mathrm{mL}\right)$ and then poured on to sterilized Petri plate. The agar plate was left to solidify at room temperature. A well of $4 \mathrm{~mm}$ was aseptically bored into the agar plate. Then, $20 \mu \mathrm{L}$ of the complexes (diluted with DMSO) was added in each well. The plates were kept at $4^{\circ} \mathrm{C}$ for 2 hours to allow the dispersal and then incubated at $37^{\circ} \mathrm{C}$ for 24 hour.

2.2.2. Antifungal Study. The antifungal activity of some adducts was tested against the pathogenic fungus Sclerotium rolfsii by poisoned food technique using potato dextrose agar (PDA) nutrient as the medium [17]. The linear growth of the fungus in controlled manner was recorded at different concentration of the adducts. The growth inhibition of Sclerotium rolfsii over control was calculated (Table 7). The growth inhibition of fungus over control was calculated as

$$
\text { \%inhibition }(I)=\frac{C-T}{C} \times 100
$$

where $I$ is percent inhibition, $C$ is mean growth of fungus (in $\mathrm{mm}$ ) in control, and $T$ is mean growth of fungus (in $\mathrm{mm}$ ) in treatment.

\subsection{Synthesis of Axially Ligated Zirconium(IV) Porphyrins Complexes}

2.3.1. Meso-5,10,15,20-tetraphenylporphyrin [ $\left.\mathrm{H}_{2} \mathrm{TPP}\right]$. The $\mathrm{H}_{2}$ TPP was prepared by refluxing benzaldehyde and pyrrole in propionic acid by following reported literature method [18] with modification.

2.3.2. Synthesis of Axially Ligated $\operatorname{Zr}(I V)$ Porphyrins: $[\operatorname{Zr}(T P P)(Y)(X)]$. A mixture of $\operatorname{Zr}(\mathrm{acac})_{4}(1.87 \mathrm{mmol})$, meso-tetraphenylporphyrin $(3.74 \mathrm{mmol})$, and respective phenol $(0.12 \mathrm{mmol})$ with constant stirring refluxed for about 50-60 minutes (Scheme 1). The reaction course was monitored by absorption spectra of the reaction mixture. After concentration, the mixture was dissolved in minimum quantity of $\mathrm{CHCl}_{3}$ and extracted with $2 \mathrm{~N} \mathrm{NaOH}$ solution to remove excess phenols. The lower layer containing compound in $\mathrm{CHCl}_{3}$ was collected and then it was filtered through anhydrous $\mathrm{Na}_{2} \mathrm{SO}_{4}$ in order to remove water and chromatographed through basic alumina using chloroform as an eluent and recrystallized from dichloromethanehexane solution $(1: 1)$. The same procedure was applied for the synthesis of all axially ligated zirconium porphyrin complexes as described above. The purified axially ligated zirconium porphyrin complexes were obtained in yields of $35-40 \%$.

$\operatorname{Zr}(\mathrm{TPP})(\mathrm{acac})(\mathrm{Oph})$. Red solid; Anal. Calcd. for $\mathrm{C}_{55} \mathrm{H}_{40} \mathrm{~N}_{4} \mathrm{O}_{3} \mathrm{Zr}$ : C 73.71, H 4.50, N 6.25; found: C 73.26, H 4.45, N 6.83; MS $\left(\mathrm{CH}_{3} \mathrm{OH}\right): \mathrm{m} / z$ calcd. for $\mathrm{C}_{55} \mathrm{H}_{40} \mathrm{~N}_{4} \mathrm{O}_{3} \mathrm{Zr}$ : 896.16; found $897.31\left([\mathrm{M}+\mathrm{H}]^{+}\right)$; IR $(\mathrm{KBr}) \nu_{\max }: 473 \mathrm{~cm}^{-1}$ $\left(v_{\mathrm{Zr}-\mathrm{N}}\right)$.

$\mathrm{Zr}(\mathrm{TPP})(\mathrm{acac})\left(\mathrm{p}-\mathrm{NH}_{2} \mathrm{phO}\right)$. Yellow solid; Anal. Calcd. For $\mathrm{C}_{55} \mathrm{H}_{41} \mathrm{~N}_{5} \mathrm{O}_{3} \mathrm{Zr}$ : C 72.50, $\mathrm{H}$ 4.54, N 7.69; found: C 72.62, H 4.52, N 7.62; MS $\left(\mathrm{CH}_{3} \mathrm{OH}\right): \mathrm{m} / z$ calcd. for $\mathrm{C}_{55} \mathrm{H}_{41} \mathrm{~N}_{5} \mathrm{O}_{3} \mathrm{Zr}$ : 911.17; found $912.01\left([\mathrm{M}+\mathrm{H}]^{+}\right)$; IR $(\mathrm{KBr}) v_{\max }: 460 \mathrm{~cm}^{-1}$ $\left(\nu_{\mathrm{Zr}-\mathrm{N}}\right)$.

$\mathrm{Zr}(\mathrm{TPP})(\mathrm{acac})\left(\mathrm{p}-\mathrm{OCH}_{3}\right.$ phO). Red solid; Anal. Calcd. for $\mathrm{C}_{56} \mathrm{H}_{42} \mathrm{~N}_{4} \mathrm{O}_{4} \mathrm{Zr}$ : $\mathrm{C}$ 72.62, $\mathrm{H}$ 4.57, $\mathrm{N}$ 6.05; found: $\mathrm{C}$ 71.23, $\mathrm{H}$ 4.96, $\mathrm{N}$ 5.62; ESI-MS $\left(\mathrm{CH}_{3} \mathrm{OH}\right): \mathrm{m} / z$ calcd. for $\mathrm{C}_{56} \mathrm{H}_{42} \mathrm{~N}_{4} \mathrm{O}_{2} \mathrm{Zr}$ : 926.18; found $927.34\left([\mathrm{M}+\mathrm{H}]^{+}\right)$; IR $(\mathrm{KBr}) \nu_{\max }: 481 \mathrm{~cm}^{-1}\left(\nu_{\mathrm{Zr}-\mathrm{N}}\right)$.

$\mathrm{Zr}(\mathrm{TPP})(\mathrm{acac})\left(\mathrm{p}-\mathrm{CH}_{3} \mathrm{phO}\right)$. Red solid; Anal. Calcd. for $\mathrm{C}_{56} \mathrm{H}_{42} \mathrm{~N}_{4} \mathrm{O}_{3} \mathrm{Zr}$ : $\mathrm{C}$ 73.90, $\mathrm{H}$ 4.65, $\mathrm{N}$ 6.16; found: $\mathrm{C}$ 73.65, $\mathrm{H}$ 4.88, $\mathrm{N}$ 5.42; ESI-MS $\left(\mathrm{CH}_{3} \mathrm{OH}\right): \mathrm{m} / z$ calcd. for $\mathrm{C}_{56} \mathrm{H}_{42} \mathrm{~N}_{4} \mathrm{O}_{3} \mathrm{Zr}$ : 910.18; found $911.25\left([\mathrm{M}+\mathrm{H}]^{+}\right)$; IR $(\mathrm{KBr}) \nu_{\max }: 468 \mathrm{~cm}^{-1}\left(\nu_{\mathrm{Zr}-\mathrm{N}}\right)$.

$\operatorname{Zr}(T P P)($ acac $)(p-C l p h O)$. Brown solid; Anal. Calcd. for $\mathrm{C}_{55} \mathrm{H}_{39} \mathrm{ClN}_{4} \mathrm{O}_{3} \mathrm{Zr}$ : $\mathrm{C}$ 70.99, $\mathrm{H}$ 4.22, $\mathrm{N}$ 6.02; found: $\mathrm{C}$ 71.66, $\mathrm{H}$ 4.81, $\mathrm{N}$ 5.64; ESI-MS $\left(\mathrm{CH}_{3} \mathrm{OH}\right): \mathrm{m} / z$ calcd. 


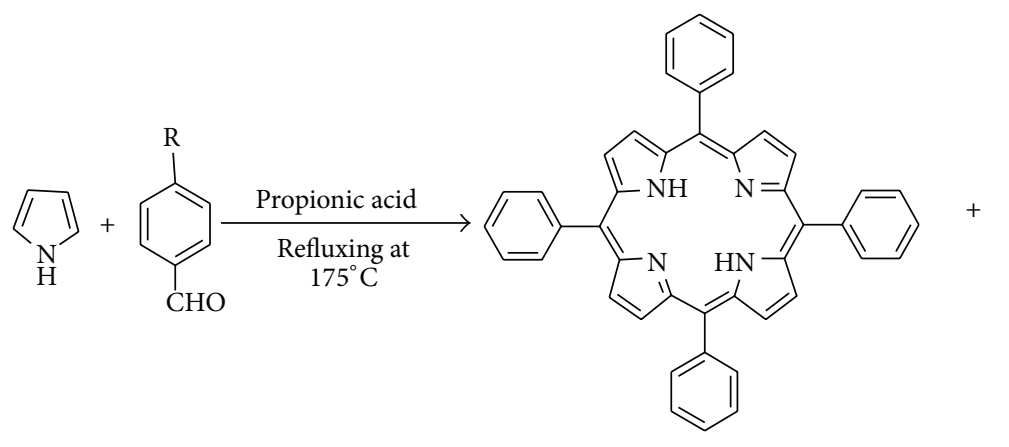

Meso-5,10,15,20-tetraphenylporphyrin

$\left(\mathrm{H}_{2} \mathrm{TPP}\right)$

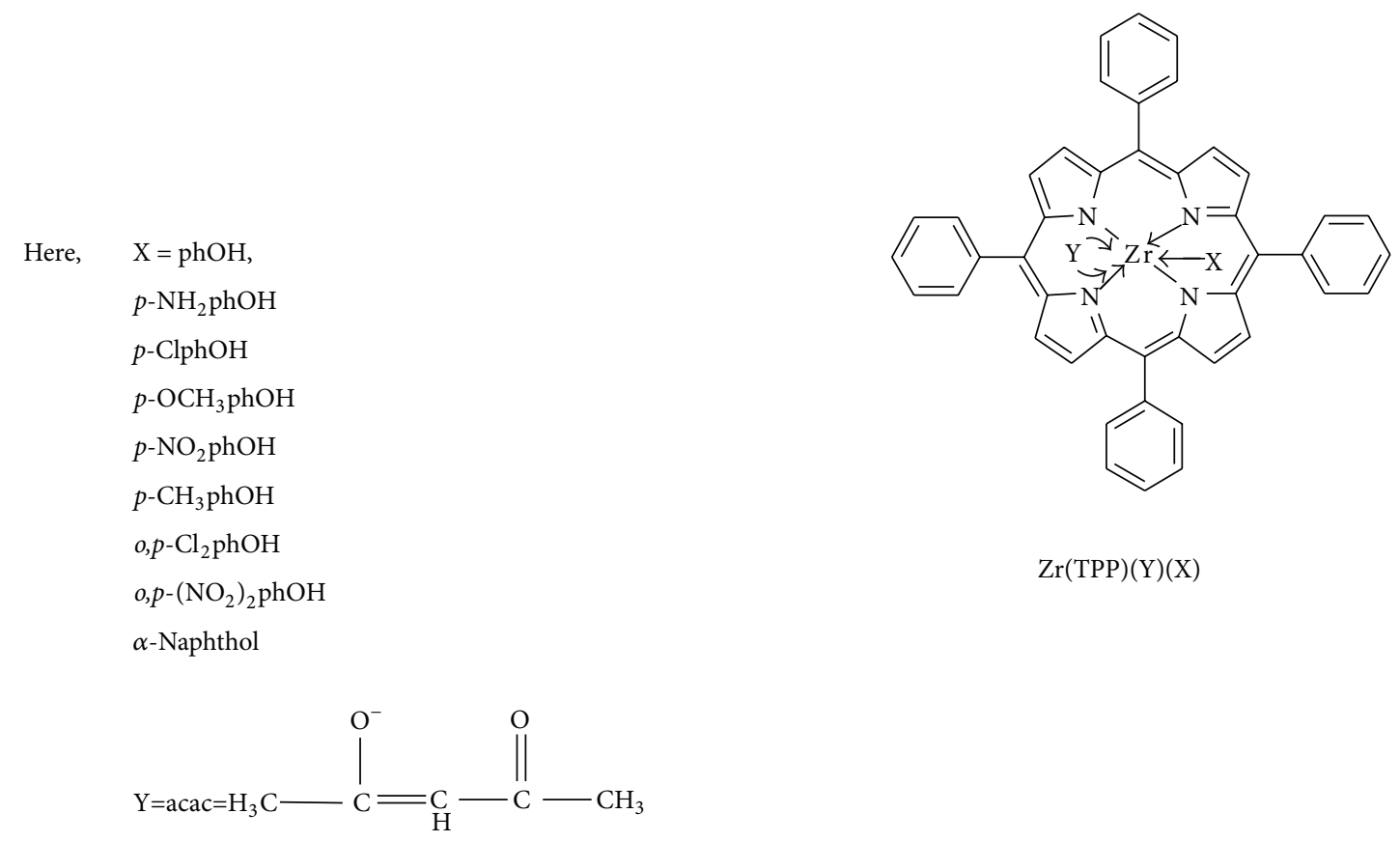

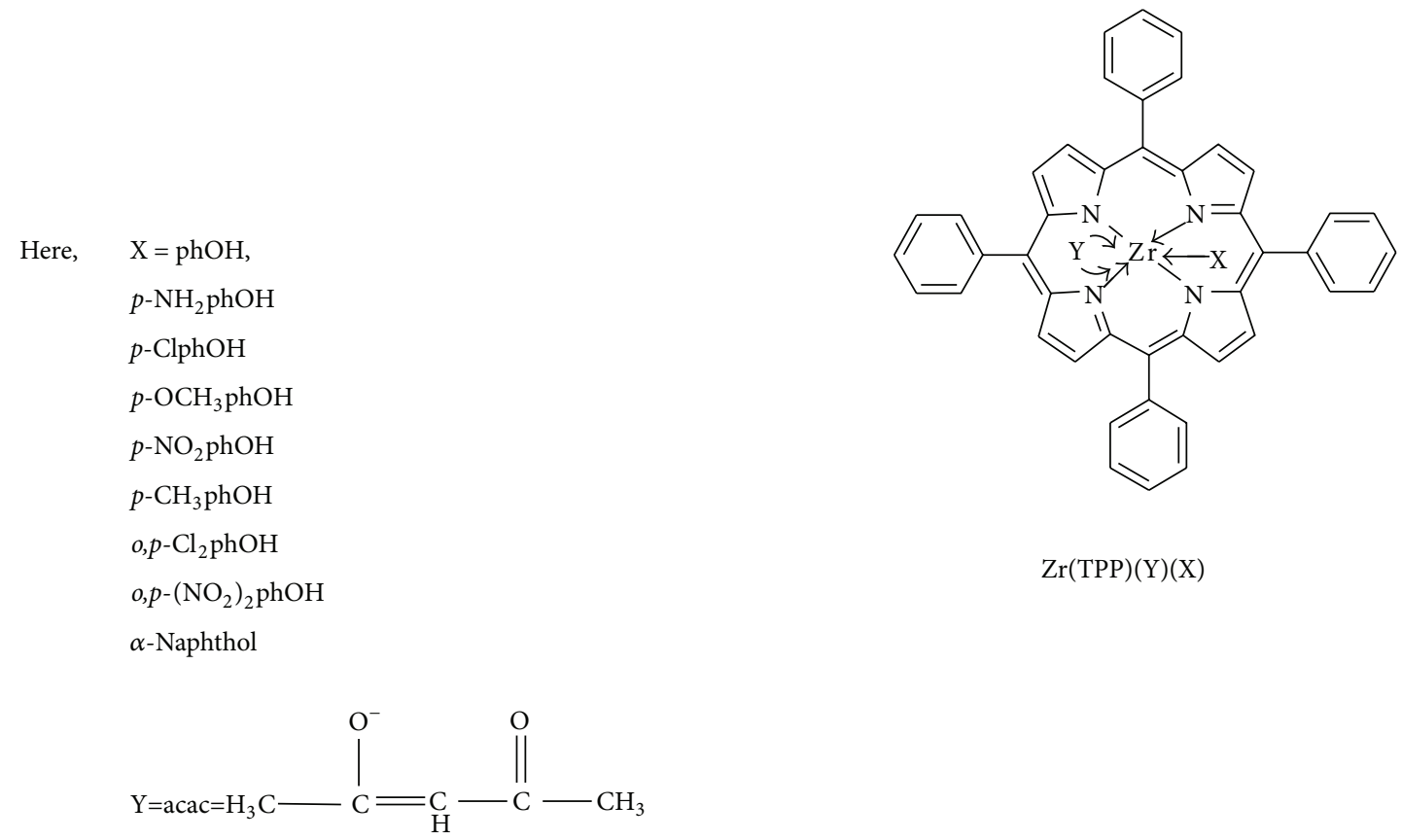

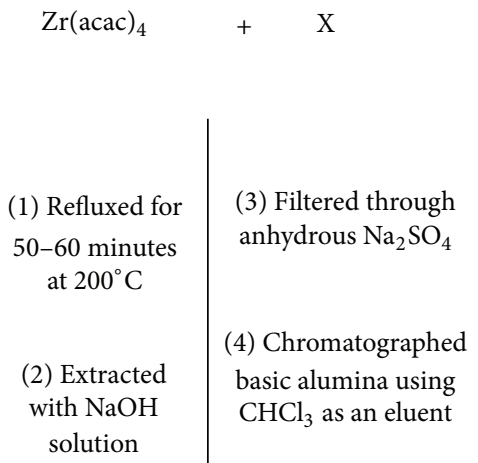

(2) Extracted with $\mathrm{NaOH}$ solution

(3) Filtered through anhydrous $\mathrm{Na}_{2} \mathrm{SO}_{4}$

(4) Chromatographed basic alumina using $\mathrm{CHCl}_{3}$ as an eluent

(5) Recrystallization

SCHEme 1: General synthetic route for the synthesis of axially ligated $\operatorname{Zr}(\mathrm{IV})$ porphyrins complexes.

for $\mathrm{C}_{55} \mathrm{H}_{39} \mathrm{ClN}_{4} \mathrm{O}_{3} \mathrm{Zr}$ : 930.61; found $931.52\left([\mathrm{M}+\mathrm{H}]^{+}\right)$; IR $(\mathrm{KBr}) \nu_{\max }: 475 \mathrm{~cm}^{-1}\left(\nu_{\mathrm{Zr}-\mathrm{N}}\right)$.

$\mathrm{Zr}(\mathrm{TPP})(\mathrm{acac})\left(\mathrm{p}-\mathrm{NO}_{2} \mathrm{phO}\right)$. Brown solid; Anal. Calcd. for $\mathrm{C}_{55} \mathrm{H}_{39} \mathrm{~N}_{5} \mathrm{O}_{5} \mathrm{Zr}$ : C 70.19, $\mathrm{H}$ 4.18, N 7.44; found: C 70.23, $\mathrm{H}$ 4.12, $\mathrm{N}$ 7.56; ESI-MS $\left(\mathrm{CH}_{3} \mathrm{OH}\right): \mathrm{m} / z$ calcd. for $\mathrm{C}_{51} \mathrm{H}_{32} \mathrm{~N}_{4} \mathrm{O}_{3} \mathrm{Zr}$ : 941.15; found $942.05\left([\mathrm{M}+\mathrm{H}]^{+}\right)$; IR $(\mathrm{KBr}) v_{\max }: 484 \mathrm{~cm}^{-1}\left(v_{\mathrm{Zr}-\mathrm{N}}\right)$.
$\mathrm{Zr}(\mathrm{TPP})($ acac $)\left(o, p-\mathrm{Cl}_{2} \mathrm{phO}\right)$. Yellow solid; Anal. Calcd. for $\mathrm{C}_{55} \mathrm{H}_{38} \mathrm{~N}_{4} \mathrm{O}_{3} \mathrm{Cl}_{2} \mathrm{Zr}$ : C 68.45, H 3.97, N 5.81; found: C 68.31, H 3.52, N 5.43; ESI-MS $\left(\mathrm{CH}_{3} \mathrm{OH}\right): \mathrm{m} / z$ calcd. For $\mathrm{C}_{55} \mathrm{H}_{38} \mathrm{~N}_{4} \mathrm{O}_{3} \mathrm{Cl}_{2} \mathrm{Zr}$ : 965.05; found $966.19\left([\mathrm{M}+\mathrm{H}]^{+}\right)$; IR $(\mathrm{KBr}) v_{\max }: 480 \mathrm{~cm}^{-1}\left(\nu_{\mathrm{Zr}-\mathrm{N}}\right)$.

$\mathrm{Zr}(\mathrm{TPP})(\mathrm{acac})\left(o, p-\left(\mathrm{NO}_{2}\right)_{2} \mathrm{phO}\right)$. Red solid; Anal. Calcd. for $\mathrm{C}_{55} \mathrm{H}_{38} \mathrm{~N}_{6} \mathrm{O}_{7} \mathrm{Zr}$ : C 66.99, $\mathrm{H}$ 3.88, $\mathrm{N}$ 8.52; found: 
TABle 1: Optical absorption data of $\mathrm{Zr}(\mathrm{TPP})(\mathrm{Y})(\mathrm{X})$ complexes in $\mathrm{CHCl}_{3}$.

\begin{tabular}{|c|c|c|}
\hline Compounds & $\begin{array}{c}B \text {-bands } \\
\lambda_{\max }(\mathrm{nm}),(\log \varepsilon)\end{array}$ & $\begin{array}{c}\text { Q-bands } \\
\lambda_{\max }(\mathrm{nm}),(\log \varepsilon)\end{array}$ \\
\hline $\mathrm{Zr}(\mathrm{TPP})(\mathrm{acac})(\mathrm{Oph})$ & $413.1,(5.074)$ & $\begin{array}{l}500.5,(4.183) \\
535.7,(4.796) \\
579.9,(5.009) \\
\end{array}$ \\
\hline $\mathrm{Zr}(\mathrm{TPP})(\mathrm{acac})\left(p-\mathrm{OCH}_{3} \mathrm{phO}\right)$ & $414.2,(5.101)$ & $\begin{array}{l}501.5,(4.197) \\
536.8,(4.812) \\
580.9,(5.031) \\
\end{array}$ \\
\hline $\mathrm{Zr}(\mathrm{TPP})(\mathrm{acac})\left(p-\mathrm{CH}_{3} \mathrm{phO}\right)$ & $413.9,(5.104)$ & $\begin{array}{l}501.7,(4.200) \\
537.4,(4.814) \\
581.4,(5.033)\end{array}$ \\
\hline $\mathrm{Zr}(\mathrm{TPP})(\mathrm{acac})\left(p-\mathrm{NO}_{2} \mathrm{phO}\right)$ & $412.9,(5.056)$ & $\begin{array}{l}501.4,(4.168) \\
535.1,(4.788) \\
580.8,(4.990) \\
\end{array}$ \\
\hline $\mathrm{Zr}(\mathrm{TPP})(\mathrm{acac})(p-\mathrm{ClphO})$ & $413.3,(5.068)$ & $\begin{array}{l}500.8,(4.177) \\
536.1,(4.795) \\
580.2,(5.005) \\
\end{array}$ \\
\hline $\mathrm{Zr}(\mathrm{TPP})(\mathrm{acac})\left(p-\mathrm{NH}_{2} \mathrm{phO}\right)$ & $415.1,(5.119)$ & $\begin{array}{l}502.9,(4.214) \\
538.9,(4.828) \\
583.5,(5.049) \\
\end{array}$ \\
\hline $\mathrm{Zr}(\mathrm{TPP})(\mathrm{acac})\left(o, p-\mathrm{Cl}_{2} \mathrm{phO}\right)$ & $411.8,(5.061)$ & $\begin{array}{l}499.2,(4.172) \\
534.3,(4.793) \\
578.8,(4.997)\end{array}$ \\
\hline $\mathrm{Zr}(\mathrm{TPP})(\mathrm{acac})\left(o, p-\left(\mathrm{NO}_{2}\right)_{2} \mathrm{phO}\right)$ & $410.9,(5.049)$ & $\begin{array}{l}498.5,(4.159) \\
532.9,(4.781) \\
578.3,(4.472)\end{array}$ \\
\hline $\operatorname{Zr}(\mathrm{TPP})(\mathrm{acac})(\alpha$-naphtholate $)$ & $412.8,(5.068)$ & $\begin{array}{l}500.3,(4.178) \\
535.4,(4.795) \\
579.7,(5.007)\end{array}$ \\
\hline
\end{tabular}

C 67.87, $\mathrm{H}$ 3.36, $\mathrm{N}$ 8.61; ESI-MS $\left(\mathrm{CH}_{3} \mathrm{OH}\right): \mathrm{m} / z$ calcd. for $\mathrm{C}_{55} \mathrm{H}_{38} \mathrm{~N}_{6} \mathrm{O}_{7} \mathrm{Zr}$ : 986.15; found $987.18\left([\mathrm{M}+\mathrm{H}]^{+}\right)$; IR $(\mathrm{KBr}) \nu_{\max }: 478 \mathrm{~cm}^{-1}\left(\nu_{\mathrm{Zr}-\mathrm{N}}\right)$.

$\operatorname{Zr}(T P P)($ acac)( $\alpha$-naphtholate). Reddish brown solid; Anal. Calcd. for $\mathrm{C}_{59} \mathrm{H}_{42} \mathrm{~N}_{4} \mathrm{O}_{3} \mathrm{Zr}$ : C 74.89, $\mathrm{H}$ 4.47, N 5.92; found: $\mathrm{C}$ 74.83, $\mathrm{H}$ 4.41, $\mathrm{N}$ 5.95; $\mathrm{MS}\left(\mathrm{CH}_{3} \mathrm{OH}\right): \mathrm{m} / z$ calcd. for $\mathrm{C}_{59} \mathrm{H}_{42} \mathrm{~N}_{4} \mathrm{O}_{3} \mathrm{Zr}$ : 946.21; found $947.32\left([\mathrm{M}+\mathrm{H}]^{+}\right)$; IR $(\mathrm{KBr}) \nu_{\max }: 473 \mathrm{~cm}^{-1}\left(\nu_{\mathrm{Zr}-\mathrm{N}}\right)$.

\section{Results and Discussion}

3.1. Synthesis and Characterization. The general synthetic route to axially ligated zirconium(IV) porphyrins is shown in Scheme 1. All of these new zirconium(IV) porphyrins were purified by column chromatography with aluminum oxide as adsorbent and were characterized by spectral data (UVvisible spectroscopy, IR spectroscopy, ${ }^{1} \mathrm{H}$ NMR spectroscopy, mass spectral data, and elemental analysis). The characterization data of the new compounds are consistent with the assigned formula. All the synthesized complexes are water insoluble.

3.1.1. Spectral Analysis of $\operatorname{Zr}(T P P)(Y)(X)$. The spectral data of the synthesized complexes (Table 1 ) revealed that the axially ligated $\mathrm{Zr}(\mathrm{IV})$ metal derivatives of porphyrin with different phenolates as an axial ligand showed hypsochromic shift (blue shift) and variation in intensities of absorption bands when compared to their respective free base porphyrin, due to incorporation of the metal ion along with phenolate in the porphyrin rings $[1,19]$. The complexes with electron donating groups in phenolates have slightly red shifted $B$ - and Qbands while those having electron withdrawing groups in phenolates have blue shifted $B$ and $Q$ bands. When the optical absorption spectra of the compounds of $\mathrm{Zr}(\mathrm{TPP})(\mathrm{Y})(\mathrm{X})$ were recorded in different solvents (Figure 1) only a marginal change in $\lambda_{\max }$ values, absorption coefficient $(\varepsilon)$, and oscillator strength $(f)$ values was observed. Data revealed that a change in polarity of the solvent results in slight change in the position of transitions but there was a significant increase in $v_{1 / 2}$ and " $f$ " values of transitions by increasing the polarity of the solvent (Table 2). The magnitude of change in " $f$ " value in axially ligated $\mathrm{Zr}(\mathrm{IV})$ metal derivatives of porphyrin revealed the relative strength of $\pi-\pi^{*}$ interactions. It was also found that, with the increase in polarity of the solvents, $B$ and $Q$ bands in axially ligated $\mathrm{Zr}(\mathrm{IV})$ metal derivatives showed red shift with progressive broadening of bands indicating that the magnitude of red shift of $B$ and $Q$ bands depends on the nature of the solvent used.

By comparing the infrared spectral data of $\mathrm{H}_{2}$ TPP and its corresponding axially ligated $\operatorname{Zr}(\mathrm{TPP})(\mathrm{Y})(\mathrm{X})$ (Table 3 ), 


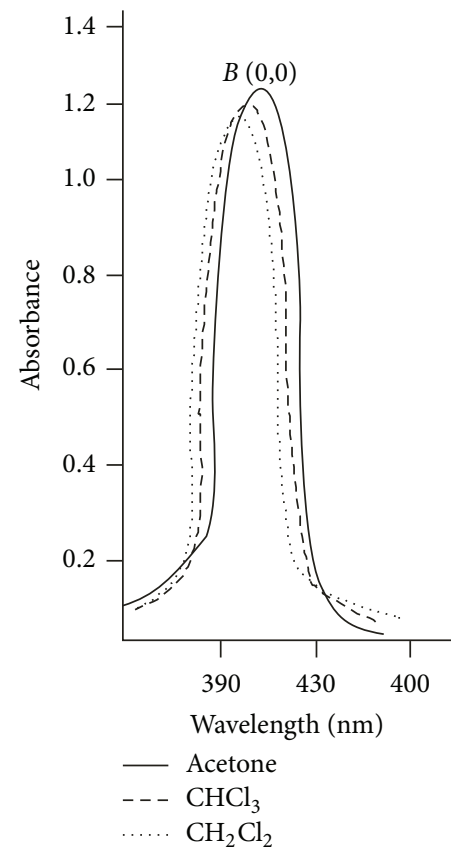

(a) Q-bands

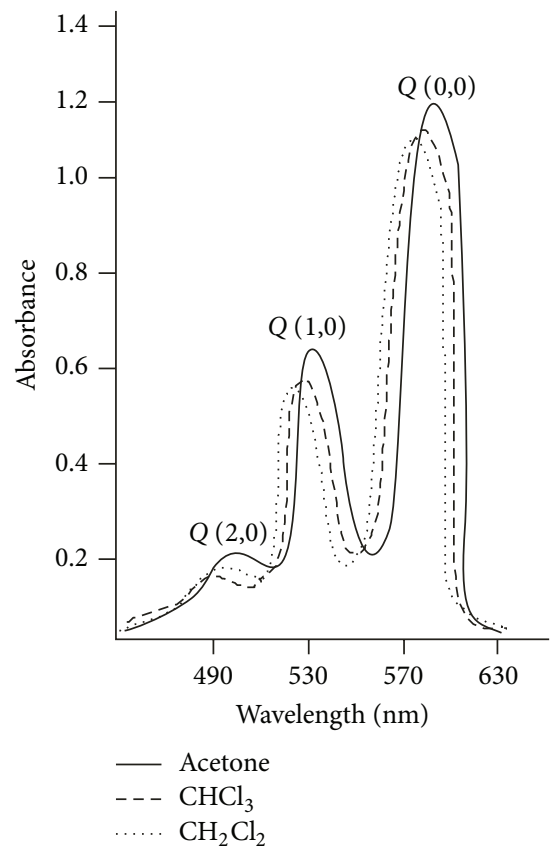

(b) $B$-bands

Figure 1: UV-vis spectra of $\mathrm{Zr}(\mathrm{TPP})(\mathrm{acac})\left(\mathrm{p}-\mathrm{OCH}_{3} \mathrm{phO}\right)$ in different solvent (- Acetone, - - - $\left.\mathrm{CHCl}_{3}, \ldots \ldots \mathrm{CH}_{2} \mathrm{Cl}_{2}\right)$.

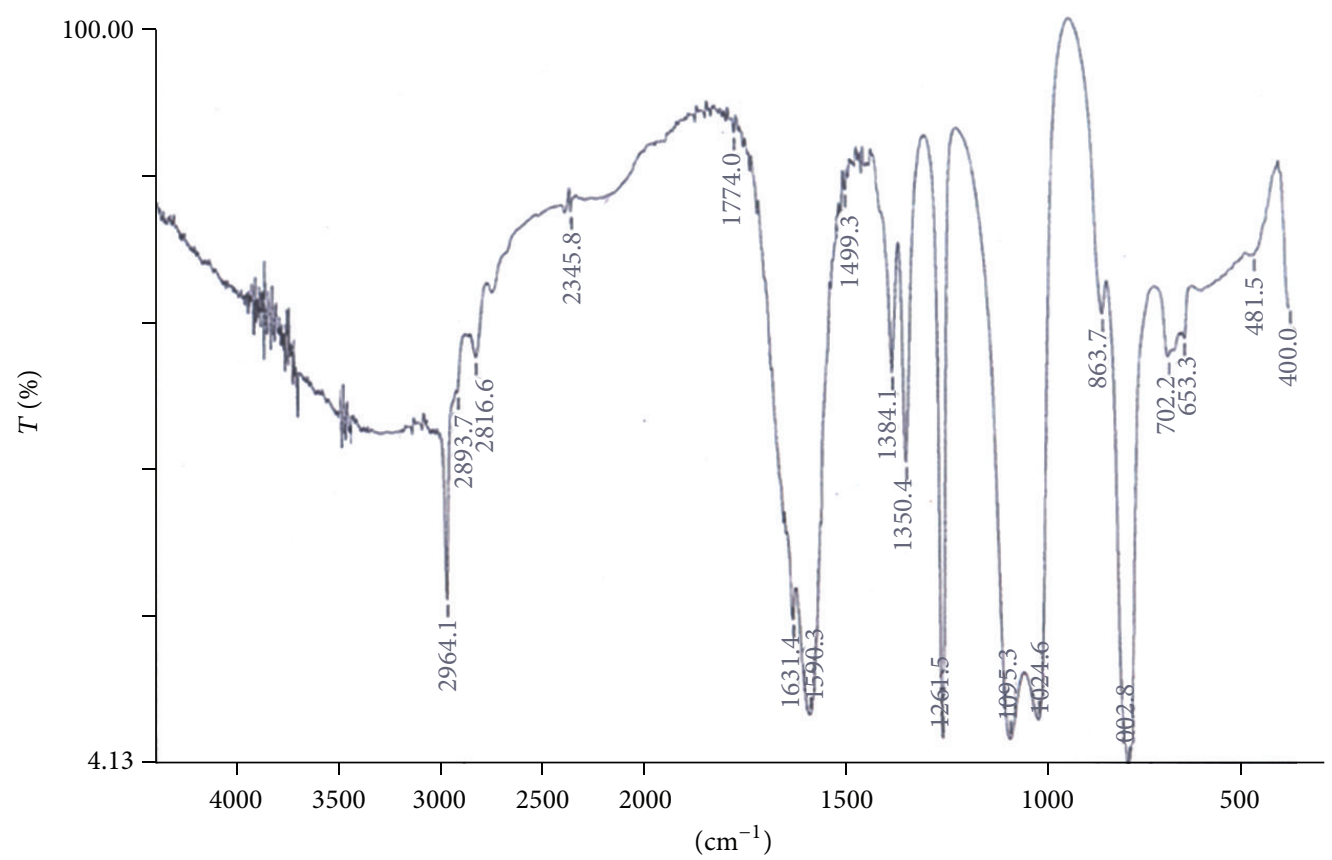

FIgURE 2: Infrared spectrum of $\mathrm{Zr}(\mathrm{TPP})(\mathrm{acac})\left(\mathrm{p}-\mathrm{OCH}_{3} \mathrm{phO}\right)$. 
TABLE 2: Optical absorption data of $\operatorname{Zr}(\mathrm{TPP})(\mathrm{Y})(\mathrm{X})$ in different solvents.

\begin{tabular}{|c|c|c|c|c|c|c|c|c|}
\hline \multirow{2}{*}{ Compounds } & \multirow{2}{*}{ Solvent } & \multicolumn{4}{|c|}{$\lambda_{\max }(\mathrm{nm}), \log \varepsilon\left(\mathrm{M}^{-1} \mathrm{~cm}^{-1}\right)$} & \multicolumn{2}{|c|}{$v_{1 / 2}\left(\mathrm{~cm}^{-1}\right)$} & \multirow{2}{*}{$\begin{array}{c}Q(0,0) \\
\quad f\end{array}$} \\
\hline & & $B(0,0)$ & $Q(2,0)$ & $Q(1,0)$ & $Q(0,0)$ & $B(0,0)$ & $Q(0,0)$ & \\
\hline \multirow{6}{*}{$\mathrm{Zr}(\mathrm{TPP})(\mathrm{acac})(\mathrm{phO})$} & \multirow{2}{*}{ Acetone } & 413.1 & 500.5 & 535.7 & 579.9 & 1309.3 & 1067.2 & 0.235887 \\
\hline & & 5.074 & 4.183 & 4.796 & 5.009 & & & \\
\hline & \multirow{2}{*}{$\mathrm{CH}_{2} \mathrm{Cl}_{2}$} & 409.4 & 496.3 & 532.2 & 575.8 & 1241.6 & 1020.7 & 0.197404 \\
\hline & & 5.030 & 4.126 & 4.721 & 4.951 & & & \\
\hline & \multirow{2}{*}{$\mathrm{CHCl}_{3}$} & 411.3 & 498.5 & 533.4 & 577.5 & 1278.1 & 1041.1 & 0.207468 \\
\hline & & 5.042 & 4.139 & 4.735 & 4.964 & & & \\
\hline \multirow{6}{*}{$\mathrm{Zr}(\mathrm{TPP})(\mathrm{acac})\left(p-\mathrm{OCH}_{3} \mathrm{phO}\right)$} & \multirow{2}{*}{ Acetone } & 414.2 & 501.5 & 536.8 & 580.9 & 1340.2 & 1085.9 & 0.252492 \\
\hline & & 5.101 & 4.197 & 4.812 & 5.031 & & & \\
\hline & \multirow{2}{*}{$\mathrm{CH}_{2} \mathrm{Cl}_{2}$} & 409.8 & 496.4 & 530.6 & 574.9 & 1279.9 & 1039.3 & 0.207586 \\
\hline & & 5.057 & 4.172 & 4.749 & 4.965 & & & \\
\hline & \multirow{2}{*}{$\mathrm{CHCl}_{3}$} & 411.9 & 498.3 & 534.2 & 578.5 & 1312.6 & 1062.4 & 0.213671 \\
\hline & & 5.063 & 4.178 & 4.765 & 4.968 & & & \\
\hline \multirow{6}{*}{$\mathrm{Zr}(\mathrm{TPP})(\mathrm{acac})\left(p-\mathrm{CH}_{3} \mathrm{phO}\right)$} & \multirow{2}{*}{ Acetone } & 412.9 & 501.4 & 535.1 & 580.8 & 1270.3 & 1035.2 & 0.219019 \\
\hline & & 5.056 & 4.168 & 4.788 & 4.990 & & & \\
\hline & \multirow{2}{*}{$\mathrm{CH}_{2} \mathrm{Cl}_{2}$} & 409.7 & 496.3 & 532.3 & 576.4 & 1218.3 & 992.6 & 0.183752 \\
\hline & & 5.002 & 4.131 & 4.718 & 4.932 & & & \\
\hline & \multirow{2}{*}{$\mathrm{CHCl}_{3}$} & 411.2 & 499.1 & 533.8 & 577.9 & 1236.8 & 1007.9 & 0.194033 \\
\hline & & 5.012 & 4.147 & 4.729 & 4.949 & & & \\
\hline \multirow{6}{*}{$\mathrm{Zr}(\mathrm{TPP})(\mathrm{acac})\left(p-\mathrm{NO}_{2} \mathrm{phO}\right)$} & \multirow{2}{*}{ Acetone } & 410.9 & 500.2 & 536.1 & 582.5 & 1271.2 & 1033.2 & 0.256245 \\
\hline & & 5.050 & 4.156 & 4.728 & 4.901 & & & \\
\hline & \multirow{2}{*}{$\mathrm{CH}_{2} \mathrm{Cl}_{2}$} & 408.6 & 495.2 & 531.5 & 576.3 & 1218.1 & 991.3 & 0.191456 \\
\hline & & 5.010 & 4.111 & 4.513 & 4.899 & & & \\
\hline & \multirow{2}{*}{$\mathrm{CHCl}_{3}$} & 410.1 & 498.9 & 537.6 & 577.7 & 1235.9 & 1006.7 & 0.198565 \\
\hline & & 5.006 & 4.124 & 4.279 & 4.999 & & & \\
\hline \multirow{6}{*}{$\operatorname{Zr}(\mathrm{TPP})($ acac $)(\alpha$-naphtholate $)$} & \multirow{2}{*}{ Acetone } & 413.5 & 500.4 & 535.2 & 581.9 & 1272.3 & 1034.2 & 0.232365 \\
\hline & & 5.045 & 4.116 & 4.718 & 4.912 & & & \\
\hline & \multirow{2}{*}{$\mathrm{CH}_{2} \mathrm{Cl}_{2}$} & 411.5 & 497.8 & 535.6 & 577.6 & 1217.3 & 9956 & 0.182536 \\
\hline & & 5.013 & 4.113 & 4.518 & 4.922 & & & \\
\hline & \multirow{2}{*}{$\mathrm{CHCl}_{3}$} & 413.5 & 498.3 & 535.8 & 578.9 & 1235.8 & 1005.3 & 0.195632 \\
\hline & & 5.102 & 4.127 & 4.739 & 4.948 & & & \\
\hline
\end{tabular}

it is found that the band at $3447 \mathrm{~cm}^{-1}$ in $\mathrm{H}_{2}$ TPP assigned to $v(\mathrm{~N}-\mathrm{H})$ (pyrrole) stretching vibration was disappeared in metallated complexes and the characteristic $v(\mathrm{Zr}-\mathrm{N})$ vibration frequency found at $\sim 500-430 \mathrm{~cm}^{-1}$, which indicated the formation of zirconium(IV) porphyrin compounds $[20,21]$. In the spectra of all the axially ligated zirconium(IV) porphyrin complexes the incorporation of various phenolates in $\mathrm{Zr}(\mathrm{IV})$ metal derivatives of porphyrin, that is, $\operatorname{Zr}(\mathrm{TPP})(\mathrm{Y})(\mathrm{X})$, was confirmed by the appearance of $\mathrm{Zr}-\mathrm{O}$ vibrational frequencies in the range of 649$680 \mathrm{~cm}^{-1}$ indicating the coordination of phenolic oxygen to the metal via deprotonation (Figure 2). Also, the incorporation of acetylacetonate (acac) in axially ligated $\mathrm{Zr}(\mathrm{IV}$ ) derivatives was confirmed by the appearance of $\mathrm{C}=\mathrm{O}$ vibrational frequencies in the range of $1622-1641 \mathrm{~cm}^{-1}$ and $\mathrm{Zr}-\mathrm{O}$ in the range of $702-819 \mathrm{~cm}^{-1}$ corresponding to the ligation of zirconium to oxygen of phenolic and carboxylic groups, respectively $[22,23]$. Thus, the zirconium atom in the centre of porphyrin ring coordinates with the acetylacetonate and phenol group axially to form seven-coordinate complex of $\mathrm{Zr}(\mathrm{IV})$ porphyrin.

From the ${ }^{1} \mathrm{H}$ NMR data of axially ligated zirconium(IV) porphyrin complexes in $\mathrm{CDCl}_{3}$ at $298 \mathrm{~K}$ (Table 4), it is found that the $\mathrm{N}-\mathrm{H}$ protons of $\mathrm{H}_{2} \mathrm{TPP}$ appear at $-2.77 \mathrm{ppm}$. In all the zirconium(IV) porphyrins there were absence of signal related to $\mathrm{N}-\mathrm{H}$ protons and shift in other signals indicating the insertion of zirconium in porphyrin macrocycle [21]. Generally, the presence of $\mathrm{Zr}(\mathrm{IV})$ metal in the porphyrin ring shifts the resonances of the porphyrin's protons to downfield accompanied by marginal changes in the pattern. One of the important features of axially ligated $\mathrm{Zr}(\mathrm{IV})$ derivatives of porphyrins is that the metal is almost out of the plane of the porphyrin ring responsible for the production of asymmetric environment above and below the plane of the macrocycle 


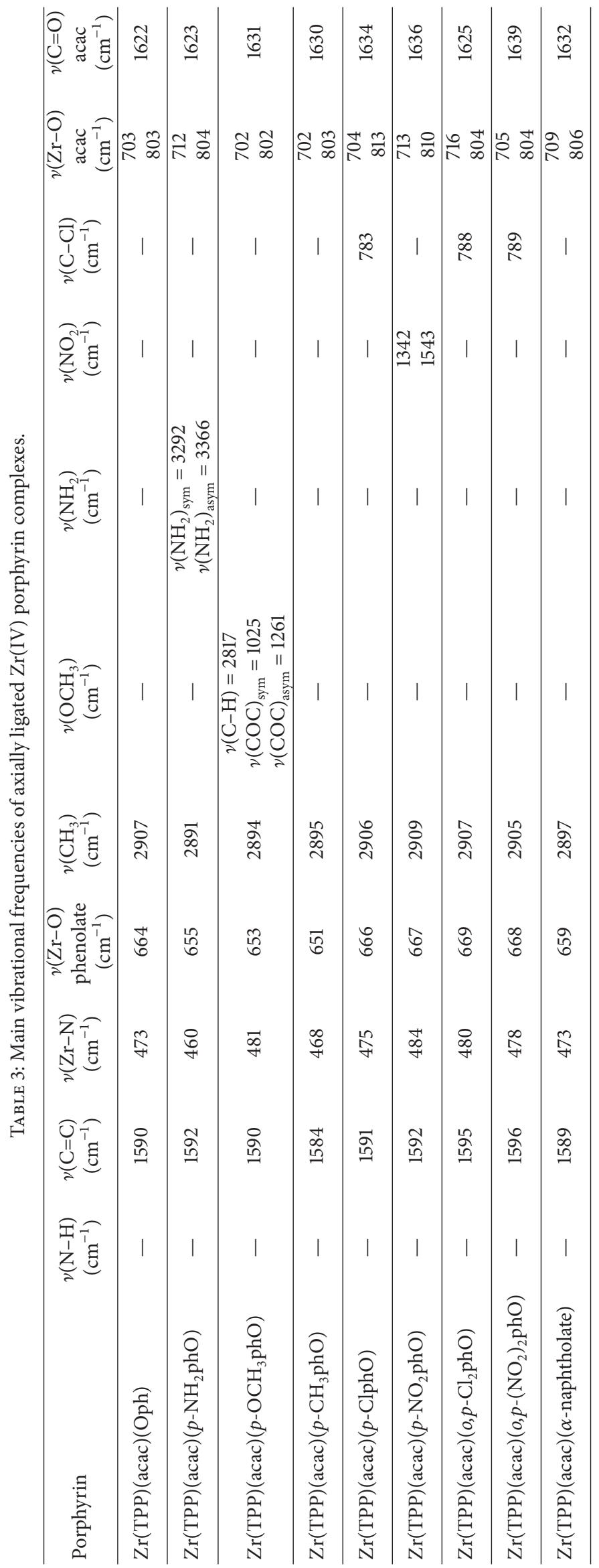




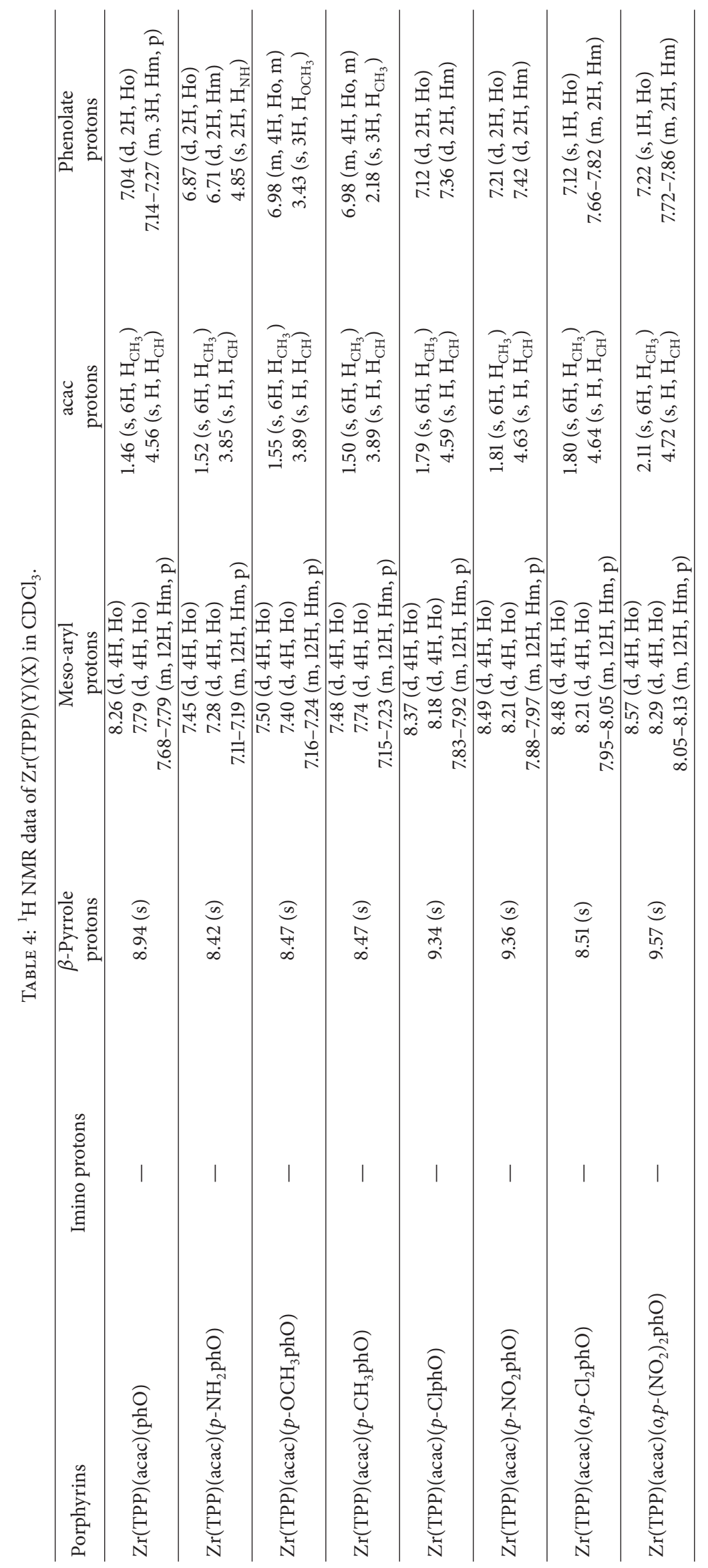


TABle 5: Summary of the fluorescence band maxima at $23 \mathrm{~K}$ in DMSO.

\begin{tabular}{lccc}
\hline Compound & \multicolumn{3}{c}{$\lambda_{\max }, \mathrm{nm}$} \\
$\mathrm{Q}(0,0)$ & $\mathrm{Q}(0,1)$ \\
\hline $\mathrm{H}_{2} \mathrm{TPP}$ & 450 & 653 & 715 \\
$\mathrm{Zr}(\mathrm{TPP})(\mathrm{acac})\left(p-\mathrm{OCH}_{3} \mathrm{phO}\right)$ & 440 & 609 & 660 \\
$\mathrm{Zr}(\mathrm{TPP})(\mathrm{acac})\left(p-\mathrm{CH}_{3} \mathrm{phO}\right)$ & 440 & 608 & 657 \\
$\mathrm{Zr}(\mathrm{TPP})(\mathrm{acac})\left(p-\mathrm{NO}_{2}\right.$ phO $)$ & 443 & 610 & 663 \\
$\mathrm{Zr}(\mathrm{TPP})(\mathrm{acac})(\alpha$-naphtholate $)$ & 441 & 608 & 653 \\
\hline
\end{tabular}

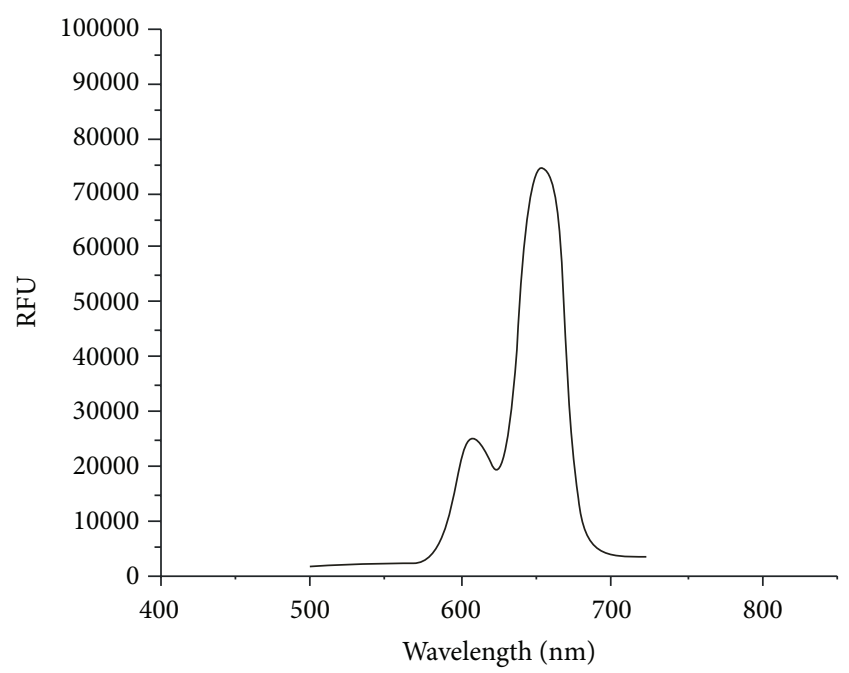

Figure 3: $S_{1} \rightarrow S_{0}$ fluorescence spectrum of $\operatorname{Zr}(\mathrm{TPP})(\mathrm{acac})(p-$ $\left.\mathrm{OCH}_{3} \mathrm{phO}\right)$ in DMSO $\left(\mathrm{C}=10^{-6} \mathrm{~mol} / \mathrm{L}, \lambda_{\text {exc }}=515 \mathrm{~nm}\right)$.

which ultimately account for the pronounced no-equivalence of the orthoprotons of the phenyl rings.

The signals of axial phenol and acetylacetonate fragment protons are shifted to higher field in comparison to the signals of porphyrin protons and also in comparison to proton signals of free phenol and acetylacetonate, respectively. These positions of protons show that axial ligand is under the influence of $\pi$-conjugated system of porphyrin macrocycle [24]. The ${ }^{1} \mathrm{H}$ NMR data of various axially ligated $\mathrm{Zr}(\mathrm{IV})$ compounds of $\mathrm{H}_{2}$ TPP revealed that the presence of electron withdrawing groups like $-\mathrm{NO}_{2},-\mathrm{Cl}$ at paraposition of phenolate caused slight downfield shift (deshielding) and the presence of electron releasing group like $-\mathrm{CH}_{3},-\mathrm{NH}_{2}$ at paraposition of phenolate caused upfield shift (shielding) of protons with respect to $\mathrm{Zr}(\mathrm{TPP})(\mathrm{acac})(\mathrm{Oph})$ which have unsubstituted phenolate as an axial ligand. This is most probably due to deshielding effect resulting from the $\sigma$-donation of electron density upon bond formation as compared to the shielding effect of the porphyrin.

In the present investigation, the variation of emission properties in free base porphyrin $\mathrm{H}_{2} \mathrm{TPP}$ and some of its corresponding axially ligated $\mathrm{Zr}(\mathrm{IV})$ porphyrins has been studied (Table 5). The free base porphyrin exhibits two emission bands at $653 \mathrm{~nm}$ and $715 \mathrm{~nm}$ corresponding to $Q(0,0)$ and $Q(0,1)$ transitions, respectively, the intensity of the $Q(0,0)$ being higher than the $Q(0,1)$ transition. The axially ligated zirconium(IV) porphyrin complexes are emissive and show intraligand fluorescence comparable to other regular metalloporphyrins (Table 5). However, the emission bands of axially ligated $\mathrm{Zr}(\mathrm{IV})$ porphyrins are blue shifted compared to free base porphyrin (Figure 3). This behavior is attributed to an enhanced spin-orbit coupling induced by the presence of the heavy-atom central metals in zirconium(IV) porphyrins complexes, which leads to a more efficient intersystem crossing from the lowest porphyrin singlet excited state ${ }^{1} S_{1}\left(\pi, \pi^{*}\right)$ to the corresponding triplet manifold and thus reduces the probability of fluorescent emission [25]. Thus, the excitation spectrum of fluorescence is in agreement with absorption spectrum.

Mass spectrometric characterization of $\mathrm{Zr}(\mathrm{TPP})(\mathrm{Y})(\mathrm{X})$ complexes employed ESI as soft ionization technique. The mass spectra of axial ligated zirconium(IV) porphyrins are characterized by the presence of the molecular ion peak for monomeric form followed by a degree of fragmentation when employing this technique, which suggested that axial ligand was labile (Figure 4).

3.1.2. Biological Studies. Antibacterial activity of all the synthesized zirconium(IV) porphyrin complexes was tested against eight bacterial strains, namely, K. pneumonia, $S$. aureus, E. faecalis, A. denitrificans, B. cereus, $M$. luteus, B. subtilis, and Campylobacter (Table 6). Our results demonstrated antibacterial activity against most of the zirconium(IV) porphyrin complexes and by comparing these complexes with $\mathrm{H}_{2}$ TPP we noted that introducing zirconium and axial ligand in $\mathrm{H}_{2}$ TPP increased antibacterial activity. Among all the complexes studied, $\mathrm{Zr}(\mathrm{TPP})(\mathrm{acac})\left(p-\mathrm{NO}_{2} \mathrm{phO}\right)$ was found to be highly potential against all the eight bacterial strains with sensitivity ranging from 1 to $2.5 \mathrm{~mm}$ zone of inhibition and even more than positive control in some cases (Table 6). $\operatorname{Zr}$ (TPP) (acac) $(\alpha$-naphtholate) was the only other complex after $\mathrm{Zr}(\mathrm{TPP})(\mathrm{acac})\left(p-\mathrm{NO}_{2}\right.$ phO) complex that showed antibacterial sensitivity against all the bacterial strains with zone of inhibition ranging from 1 to $1.75 \mathrm{~mm}$. On comparison of the antibacterial activities of synthesized complexes, we noted that for most of the bacterial strains complexes having axial ligand with electron withdrawing group have increased antibacterial activity compared to complexes having ligand with electron donating group and also compared to complex having no substituent on axial ligand, $\mathrm{Zr}(\mathrm{TPP})(\mathrm{acac})(\mathrm{phO})$.

3.1.3. Antifungal Activity. The antifungal activity of all the synthesized zirconium porphyrin complexes was tested at different concentrations against the pathogenic fungus Sclerotium rolfsii. From the results found, it has been concluded that, by increasing the concentration of the complexes $\operatorname{ZrTPP}(\mathrm{Y})(\mathrm{X})$, the colony diameter of the fungus decreases and hence percent inhibition increases. On doubling the concentration of the complexes, the percent inhibition also doubles, which shows linear relationship between concentration and percent inhibition. The increase in antimicrobial activity is due to faster diffusion of metal complexes as a whole through the cell membrane or due to combined activity effect of the metal and the ligand 


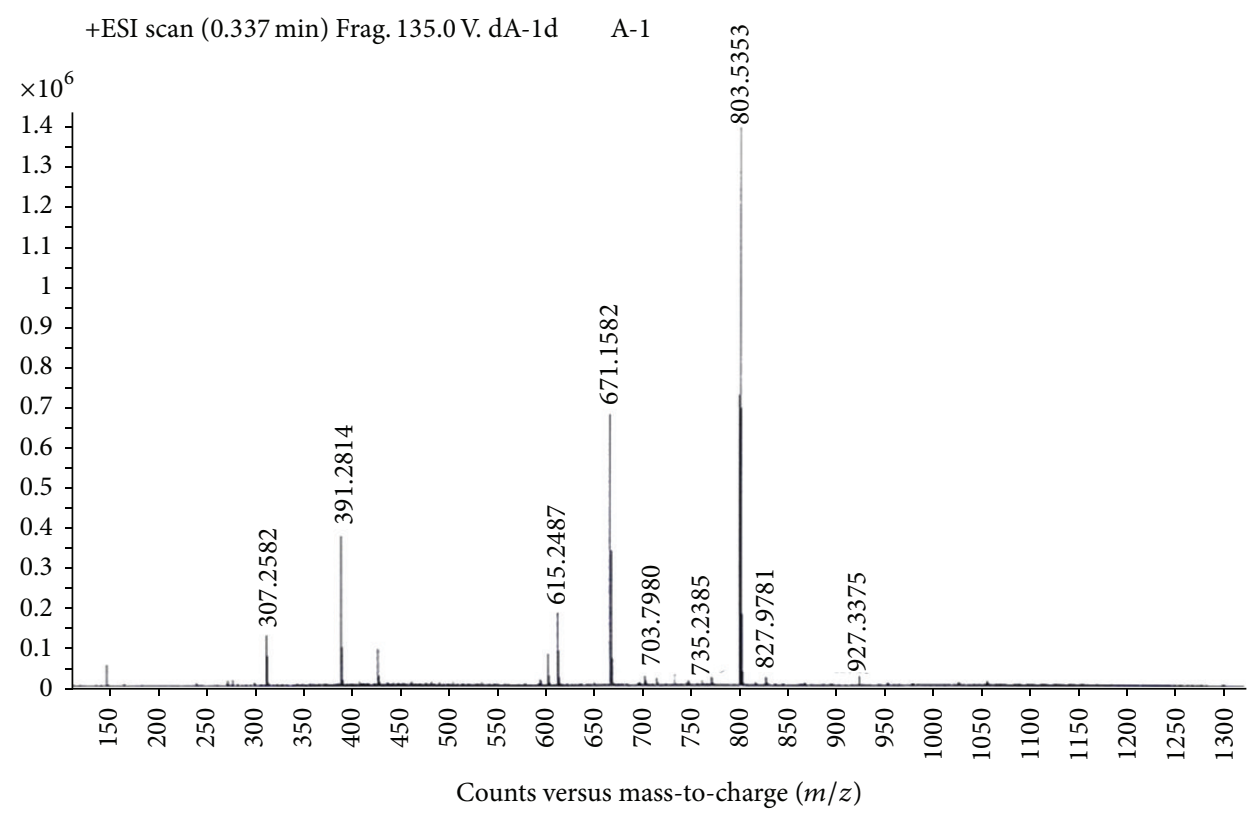

FIgURE 4: Mass spectrum of $\mathrm{Zr}(\mathrm{TPP})(\mathrm{acac})\left(\mathrm{p}-\mathrm{OCH}_{3} \mathrm{phO}\right)$ in methanol.

TABLE 6: In vitro antibacterial evaluation of free base porphyrin and the corresponding zirconium(IV) porphyrin complexes.

\begin{tabular}{|c|c|c|c|c|c|c|c|c|}
\hline PORPHYRIN & K. pneumoniae & S. aureus & E. faecalis & A. denitrificans & B. cereus & M. luteus & B. subtilis & Campylobacter \\
\hline $\mathrm{H}_{2} \mathrm{TPP}$ & - & - & 1 & - & - & - & - & - \\
\hline $\mathrm{Zr}(\mathrm{TPP})(\mathrm{acac})(\mathrm{phO})$ & - & - & 1.25 & - & - & - & - & - \\
\hline $\mathrm{Zr}(\mathrm{TPP})(\mathrm{acac})\left(p-\mathrm{NH}_{2} \mathrm{phO}\right)$ & - & - & - & 1.5 & - & - & - & - \\
\hline $\mathrm{Zr}(\mathrm{TPP})(\mathrm{acac})(p-\mathrm{ClphO})$ & - & - & - & - & - & - & - & 1.5 \\
\hline $\mathrm{Zr}(\mathrm{TPP})(\mathrm{acac})\left(p-\mathrm{OCH}_{3} \mathrm{phO}\right)$ & - & - & - & 1 & - & - & - & - \\
\hline $\operatorname{Zr}(\mathrm{TPP})(\mathrm{acac})(\alpha$-naphtholate $)$ & 1 & 1.15 & 1.1 & 1.25 & 1.1 & 1.5 & 1.75 & 1 \\
\hline $\mathrm{Zr}(\mathrm{TPP})(\mathrm{acac})\left(p-\mathrm{NO}_{2} \mathrm{phO}\right)$ & 2 & 1 & 1.5 & 1.5 & 1.2 & 1.4 & 2.5 & 1.5 \\
\hline $\mathrm{Zr}(\mathrm{TPP})(\mathrm{acac})\left(p-\mathrm{CH}_{3} \mathrm{phO}\right)$ & 1 & 0.7 & 1.7 & - & 0.9 & - & 0.7 & 0.7 \\
\hline $\mathrm{Zr}(\mathrm{TPP})(\mathrm{acac})\left(o, p-\mathrm{Cl}_{2} \mathrm{phO}\right)$ & - & - & - & 0.9 & - & - & - & 1.25 \\
\hline $\mathrm{Zr}(\mathrm{TPP})(\mathrm{acac})\left(o, p-\left(\mathrm{NO}_{2}\right)_{2} \mathrm{phO}\right)$ & - & 1.25 & 1.25 & - & - & 2 & - & 1.5 \\
\hline Control chloramphenicol & 2.5 & 2.1 & 1.4 & 2 & - & 2.25 & 2 & 2 \\
\hline
\end{tabular}

$[26,27]$. It is concluded that most of the synthesized compounds showed overall good activity. However, some complexes, namely, $\mathrm{Zr}(\mathrm{TPP})(\mathrm{acac})(\mathrm{phO}), \operatorname{Zr}(\mathrm{TPP})(\mathrm{acac})(o, p-$ $\left.\mathrm{Cl}_{2} \mathrm{phO}\right)$, and $\mathrm{Zr}(\mathrm{TPP})(\mathrm{acac})\left(o, p-\left(\mathrm{NO}_{2}\right)_{2} \mathrm{phO}\right)$, showed negligible results at given concentrations and the data for only those complexes has been provided which showed significant results (Table 7 ).

It is interesting to note that most of the synthesized axially ligated complexes were found to be more active $\left(\mathrm{IC}_{50}=\sim 26-\right.$ $196 \mu \mathrm{g} / \mathrm{mL})$ than the corresponding free base ligand $\left(\mathrm{IC}_{50}=\right.$ $212.24 \mu \mathrm{g} / \mathrm{mL})$ with $\mathrm{Zr}(\mathrm{TPP})(\mathrm{acac})\left(p-\mathrm{CH}_{3}\right.$ phO) appearing to be the most potent. The selectivity might be resulting from the well-established structural differences between fungal and bacterial cells, although the exact reasons remain as yet unclear [28].

\section{Conclusion}

A detailed analysis of ultraviolet-visible (UV-vis), proton nuclear magnetic resonance ( ${ }^{1} \mathrm{H}$ NMR) spectroscopy, infrared (IR) spectroscopy, fluorescence and mass spectroscopic studies, and elemental analysis suggested the transformation from free base porphyrins to zirconium(IV) porphyrins. The spectroscopic data revealed the ligation of acetylacetonate and different phenolates at axial position on $\mathrm{Zr}(\mathrm{IV})$ metal atom in $[\mathrm{Zr}(\mathrm{TPP})(\mathrm{acac})(\mathrm{X})]$. Therefore the coordination number of central metal ions is seven and the zirconium is expected to be above the porphyrin plane. Among all the complexes prepared $[\mathrm{Zr}(\mathrm{TPP})(\mathrm{acac})(p-$ $\mathrm{NO}_{2}$ phO)] was found to be highly potential against all the eight bacterial strains and even more than positive control 
TABLE 7: In vitro evaluation of complexes against Sclerotium rolfsii. Mean colony diameter of control C $=90 \mathrm{~mm}$.

\begin{tabular}{|c|c|c|c|c|}
\hline Name of the complex & Concentration $(\mu \mathrm{g} / \mathrm{mL})$ & Colony diameter $(\mathrm{mm})$ & $\begin{array}{c}\text { \% Inhibition } \\
I=[(C-T) / C] \times 100\end{array}$ & $\mathrm{IC}_{50}(\mu \mathrm{g} / \mathrm{mL})$ \\
\hline \multirow{3}{*}{$\mathrm{H}_{2} \mathrm{TPP}$} & 100 & 66 & 26.66 & \multirow{3}{*}{212.24} \\
\hline & 200 & 48 & 46.66 & \\
\hline & 300 & 28 & 68.89 & \\
\hline \multirow{3}{*}{$\mathrm{Zr}(\mathrm{TPP})(\mathrm{acac})\left(p-\mathrm{NH}_{2} \mathrm{phO}\right)$} & 100 & 57 & 36.66 & \multirow{3}{*}{180.61} \\
\hline & 200 & 39 & 56.66 & \\
\hline & 300 & 11 & 87.77 & \\
\hline \multirow{3}{*}{$\operatorname{Zr}(\mathrm{TPP})(\mathrm{acac})(p-\mathrm{ClphO})$} & 100 & 61 & 32.22 & \multirow{3}{*}{159.42} \\
\hline & 200 & 43 & 52.22 & \\
\hline & 300 & 12 & 86.66 & \\
\hline \multirow{3}{*}{$\mathrm{Zr}(\mathrm{TPP})(\mathrm{acac})\left(p-\mathrm{OCH}_{3} \mathrm{phO}\right)$} & 100 & 65 & 27.77 & \multirow{3}{*}{196.46} \\
\hline & 200 & 41 & 54.44 & \\
\hline & 300 & 27 & 70 & \\
\hline \multirow{3}{*}{$\operatorname{Zr}(\mathrm{TPP})(\mathrm{acac})(\alpha$-naphtholate $)$} & 100 & 33 & 53.33 & \multirow{3}{*}{102.75} \\
\hline & 200 & 30 & 66.66 & \\
\hline & 300 & 8 & 91.11 & \\
\hline \multirow{3}{*}{$\mathrm{Zr}(\mathrm{TPP})(\mathrm{acac})\left(p-\mathrm{NO}_{2} \mathrm{phO}\right)$} & 100 & 35 & 51.11 & \multirow{3}{*}{91.87} \\
\hline & 200 & 23 & 73.33 & \\
\hline & 300 & 7 & 92.22 & \\
\hline \multirow{3}{*}{$\mathrm{Zr}(\mathrm{TPP})(\mathrm{acac})\left(p-\mathrm{CH}_{3} \mathrm{phO}\right)$} & 100 & 35 & 61.11 & \multirow{3}{*}{26.02} \\
\hline & 200 & 21 & 77.77 & \\
\hline & 300 & 7 & 92.22 & \\
\hline
\end{tabular}

in some cases. Also, antifungal activity of the synthesized complexes shows that these complexes have potential against fungal growth.

\section{Conflict of Interests}

The authors declare that there is no conflict of interests regarding the publication of this paper.

\section{References}

[1] G. D. Bajju, G. Devi, S. Katoch et al., "Synthesis, spectroscopic, and biological studies on new zirconium(IV) porphyrins with axial ligand," Bioinorganic Chemistry and Applications, vol. 2013, Article ID 903616, 15 pages, 2013.

[2] I. Stojiljkovic, B. D. Evavold, and V. Kumar, "Antimicrobial properties of porphyrins," Expert Opinion on Investigational Drugs, vol. 10, no. 2, pp. 309-320, 2001.

[3] A. A. Fadda, R. E. El-Mekawy, A. El-Shafei, H. S. Freeman, D. Hinks, and M. El-Fedawy, "Design, synthesis, and pharmacological screening of novel porphyrin derivatives," Journal of Chemistry, vol. 2013, Article ID 340230, 11 pages, 2013.

[4] Y. Ni, "Metalloporphyrins and functional analogues as MRI contrast agents," Current Medical Imaging Reviews, vol. 4, no. 2, pp. 96-112, 2008.

[5] N. A. Antonova, V. P. Osipova, M. N. Kolyada, N. O. Movchan, E. R. Milaeva, and Y. T. Pimenov, "Study of the antioxidant properties of porphyrins and their complexes with metals," Macroheterocycles, vol. 3, no. 2-3, pp. 139-144, 2010.
[6] M. Yuasa, K. Oyaizu, H. Murata, Y. Sahara, T. Hatsugai, and A. Ogata, "Antioxidant and anticancer properties of metalloporphyrins embedded in liposomes," Journal of Oleo Science, vol. 56, no. 2, pp. 87-93, 2007.

[7] K. Rajesh, A. K. Rahiman, K. S. Bharathi, S. Sreedaran, V. Gangadevi, and V. Narayanan, "Spectroscopic, redox and biological studies of push-pull porphyrins and their metal complees," Bulletin of the Korean Chemical Society, vol. 31, no. 9, pp. 26562664, 2010

[8] J. Bozja, J. Sherrill, S. Michielsen, and I. Stojiljkovic, "Porphyrinbased, light-activated antimicrobial materials," Journal of Polymer Science A: Polymer Chemistry, vol. 41, no. 15, pp. 2297-2303, 2003.

[9] E. V. Motorina and T. N. Lomova, "Formation of supramolecular complex between imidazole and dichloro(5,10,15,20tetraphenylporphinato)zirconium(IV)," Russian Journal of General Chemistry, vol. 80, no. 4, pp. 842-848, 2010.

[10] A. Falber, B. P. Burton-Pye, I. Radivojevic et al., "Ternary porphyrinato HfIV and ZrIV polyoxometalate complexes," European Journal of Inorganic Chemistry, no. 17, pp. 2459-2466, 2009.

[11] L. A. Tomachynski, V. Y. Chernii, H. N. Gorbenko, V. V. Filonenko, and S. V. Volkov, "Synthesis, spectral properties, and antitumor activity of a new axially substituted phthalocyanine complex of zirconium (IV) with citric acid," Chemistry and Biodiversity, vol. 1, no. 6, pp. 862-867, 2004.

[12] I. N. Tretyakova, V. Y. Chernii, L. A. Tomachynski, and S. V. Volkov, "Synthesis and luminescent properties of new zirconium(IV) and hafnium(IV) phthalocyanines with various 
carbonic acids as out-planed ligands," Dyes and Pigments, vol. 75, no. 1, pp. 67-72, 2007.

[13] V. Kovalska, M. Losytskyy, V. Chernii et al., "Studies of antifibrillogenic activity of phthalocyanines of zirconium containing out-of-plane ligands," Bioorganic and Medicinal Chemistry, vol. 20, no. 1, pp. 330-334, 2012.

[14] G. D. Bajju, S. K. Anand, and S. Kundan, "Synthesis and characterization of zirconium (IV) derivatives of meso-tetra(pmethylphenyl)porphyrin with acetylacetonate and different phenolates at axial positions," Oriental Journal of Chemistry, vol. 28, no. 1, pp. 417-432, 2012.

[15] G. D. Bajju, S. K. Anand, and S. Kundan, "Synthesis and spectroscopic studies of zirconium(IV) porphyrins with acetylacetonate and phenolates at axial positions," Oriental Journal of Chemistry, vol. 28, no. 1, pp. 449-462, 2012.

[16] F. Oke, B. Aslim, S. Ozturk, and S. Altundag, "Essential oil composition, antimicrobial and antioxidant activities of Satureja cuneifolia Ten," Food Chemistry, vol. 112, no. 4, pp. 874-879, 2009.

[17] J. M. Vincent, "Distortion of fungal hyphæ in the presence of certain inhibitors," Nature, vol. 159, no. 4051, article 850, 1947.

[18] A. D. Adler, F. R. Longo, J. D. Finarelli, J. Goldmacher, J. Assour, and L. Korsakoff, "A simplified synthesis for mesotetraphenylporphin," Journal of Organic Chemistry, vol. 32, no. 2, p. 476, 1967.

[19] E. Fagadar-Cosma, D. Vlascici, and G. Fagadar-Cosma, "Monomer and sandwich type dimmer complexes of $\mathrm{Zr}$ (IV) with meso-tetraphenylporphyrin. Synthesis and comparative IR, UV- vis and HPLC behavior," in Proceedings of the 12th Symposium on Analytical and Environmental Problems, Szeged, pp. 25-29, Szeged, Hungary, September 2005.

[20] Z.-C. Sun, Y.-B. She, Y. Zhou, X.-F. Song, and K. Li, "Synthesis, characterization and spectral properties of substituted tetraphenylporphyrin iron chloride complexes," Molecules, vol. 16, no. 4, pp. 2960-2970, 2011.

[21] D. Vlascici, O. Bizerea-Spiridon, and E. Fagadar-Cosma, "Metalloporphyrin based fluoride-selective electrode," in Proceedings of the 13th Symposium on Analytical and Environmental Problems, pp. 92-95, Szeged, Hungary, September 2006.

[22] Q. Ming-Hui, L. Guo-Ya, S. Tong-Shun, and X. Jin-Jie, "Syntheses and photo-electronic properties of lanthanide acetyacetone benzoporphyrins," Chemical Research in Chinese Universities, vol. 20, no. 1, pp. 118-220, 2004.

[23] Z. Zhi-xin, L. Xiang-qing, W. Xing-quao, and L. Guo-ya, "Lanthanide complexes with acetylcetonate and 5,10,15,20tetra(para(4-chlorobenzoyloxy)phenyl) porphyrin," Chemical Research in Chinese Universities, vol. 16, no. 3, pp. 259-262, 2000.

[24] Y. S. Gerasymchuk, V. Y. Chernii, L. A. Tomachynskii, M. Kowalska, J. Legendziewicz, and S. Radzki, "Correlation between computer models of structure of 5-sulfosalicylato $\mathrm{Zr}(\mathrm{IV})$ phthalocyanine with results obtained by NMR, ESI-MS and UV-Vis spectra," Optical Materials, vol. 32, no. 9, pp. 11931201, 2010.

[25] G. Knor and A. Strasser, "Coexisting intraligand fluorescence and phosphorescence of hafnium(IV) and thorium(IV) porphyrin complexes in solution," Inorganic Chemistry Communications, vol. 5, no. 11, pp. 993-995, 2002.

[26] Z. Changfu, T. Xuexin, W. Dong et al., "An unsymmetrical porphyrin and its metal complexes: synthesis, spectroscopy, thermal analysis and liquid crystal properties," Journal of the Serbian Chemical Society, vol. 74, no. 10, pp. 1097-1104, 2009.
[27] L. Mishra and V. K. Singh, "Synthesis, structural and antifungal studies of $\mathrm{Co}(\mathrm{II}), \mathrm{Ni}(\mathrm{II}), \mathrm{Cu}(\mathrm{II})$ and $\mathrm{Zn}(\mathrm{II})$ complexes with new schiff bases bearing benzimidazoles," Indian Journal of Chemistry, vol. 32, no. 5, pp. 446-457, 1993.

[28] B. Thati, A. Noble, R. Rowan et al., "Mechanism of action of coumarin and silver(I)-coumarin complexes against the pathogenic yeast Candida albicans," Toxicology in Vitro, vol. 21, no. 5, pp. 801-808, 2007. 

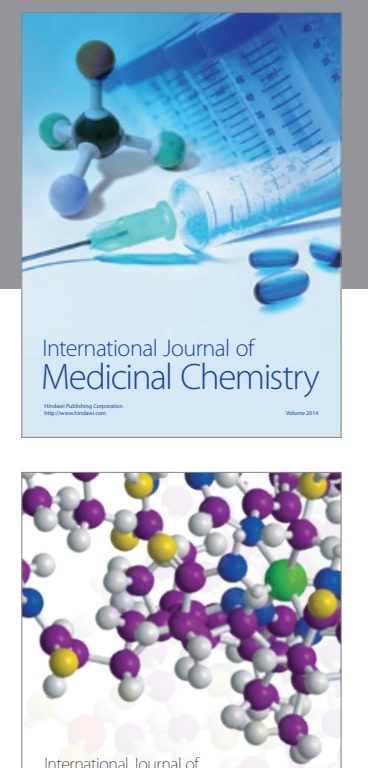

\section{Carbohydrate} Chemistry

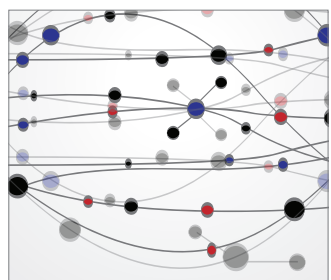

The Scientific World Journal
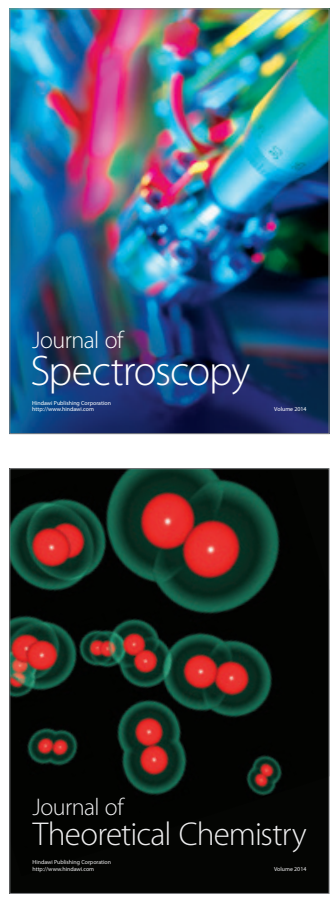
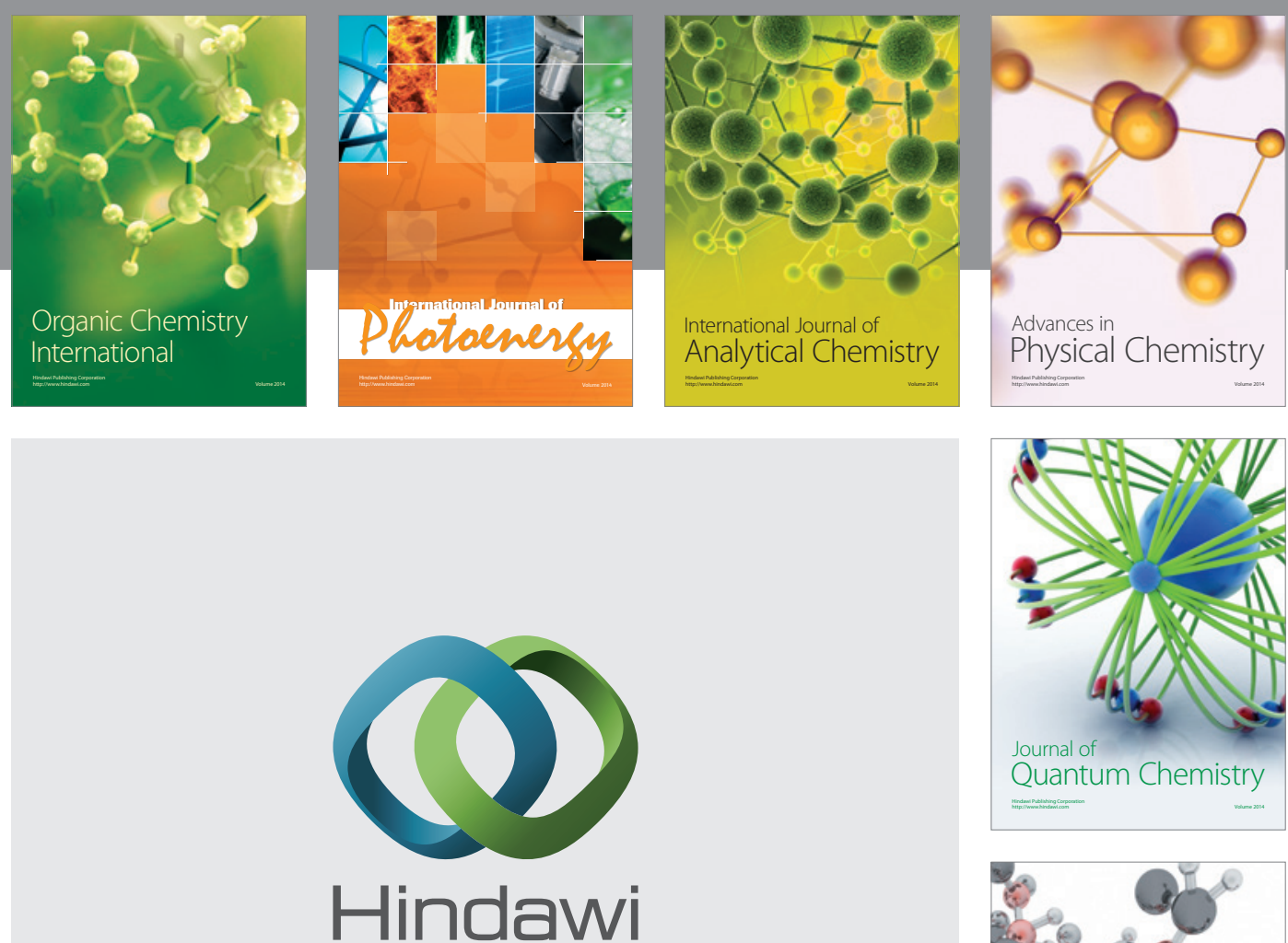

Submit your manuscripts at

http://www.hindawi.com

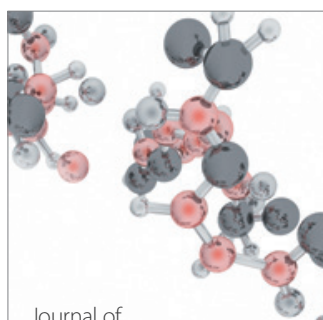

Analytical Methods

in Chemistry

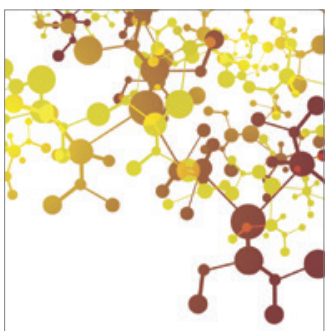

Journal of

Applied Chemistry

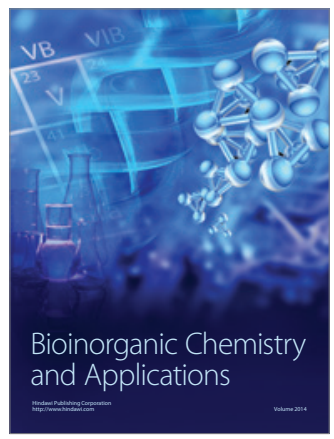

Inorganic Chemistry
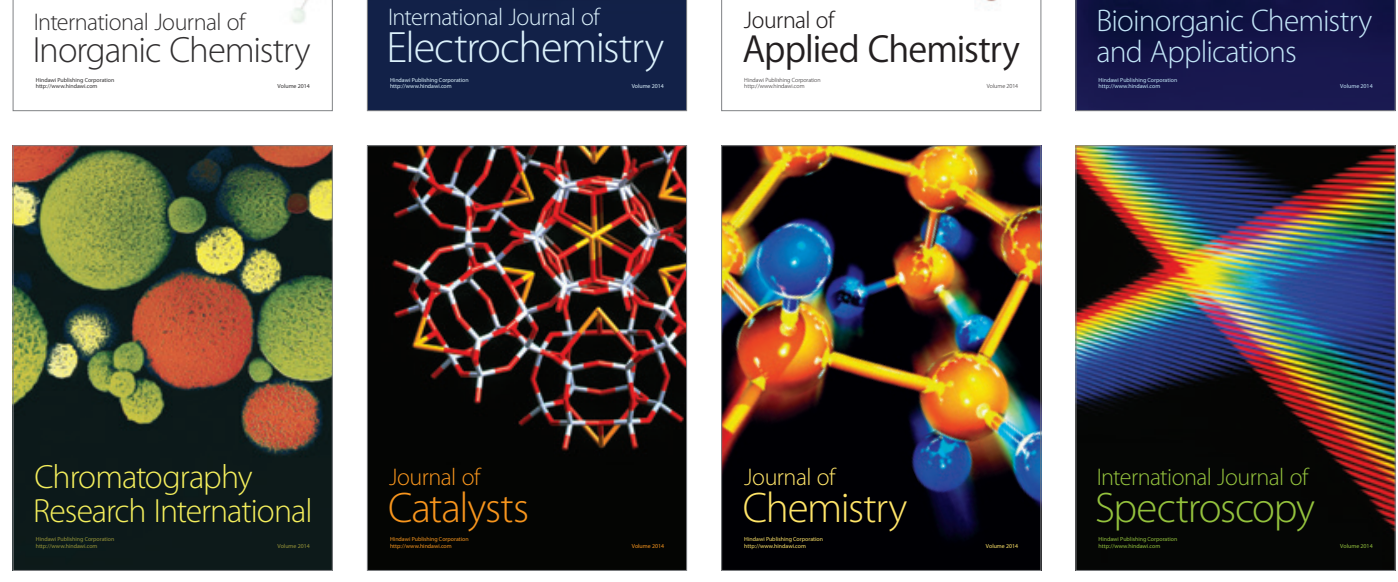